UDC 378+004

DOI https://doi.org/10.24919/2308-4863/44-3-36

Olha FEDOROVA, orcid.org/0000-0002-7594-6066

Candidate of Philological Sciences, Associate Professor at English Language Department for Maritime Officers (Abridged Program)

Kherson State Maritime Academy (Kherson, Ukraine) fedorova.olena2406@gmail.com

Natalia BOBRYSHEVA, orcid.org/0000-0002-4449-954X Candidate of Pedagogical Sciences, Associate Professor at English Language Department for Deck Officers Kherson State Maritime Academy (Kherson, Ukraine) natalyluchka1502@gmail.com

\title{
METHODOLOGY OF BLENDED LEARNING FOR MARITIME OFFICERS OF SENIOR COURSES WITH INVOLVEMENT OF THE LATEST INFORMATIONAL TECHNOLOGIES
}

The article highlights the methodology of implementing a modern educational approach - blended learning - in the study of Maritime English with the involvement of online platforms. The study found that the educational process at the Kherson State Maritime Academy (hereinafter - KSMA) integrates several types of educational activities on the principle of blended learning: traditional learning on the basis of communicative-competence approach and online learning in the form of computer training modules. The introduction of the blended learning methodology in the KSMA became possible due to the use of the Moodle learning management system, which implements online learning in asynchronous and synchronous approaches. The involvement of instructors in the communicative-competence approach both in teaching Maritime English in classrooms (classes based on the model of ESA structures) and usage of special computer training courses has enabled distance learning and deeper social communication between senior students outside the classroom. The organization of practical classes according to the communicativecompetence approach is determined, firstly, by its focus on the student, and, secondly, by orientation on communication both in the audience during practical classes and outside - in real time and social networks. The hierarchical structure of learning within the communicative-competence approach involves the structuring of large topics by modules, which are divided into separate units (lessons), subjected to its own purpose and interconnected with others. The construction of practical classes and online courses allows students to master gradually English-language competencies. Assessment of these competencies includes computer-based assessment using a learning management system and assessing the speaking skills of future maritime professionals in real time face-to-face with the instructor. Analyzing the computer-based knowledge assessment techniques based on the Moodle platform, it was found that the content of the tests is based on the real context or situations on the ship, and according to the form the dominant position is shared by multiple choice tests, compliance tests, tests to fill in the gaps, presented in combination with texts, audio and video materials. The final assessment of the English-language competencies of future maritime professionals is based on the methods of interview and discussion, which simulates the real conditions of the professional interview.

Key words: blended learning, online learning, learning management system, computer training module, communicative and competency approach.

Ольга ФЕДОРОВА, orcid.org/0000-0002-7594-6066 кандидат філологічних наук, дочент кафедри англійської мови з підготовки морських фахівиів за скороченою програмою

Херсонської державної морської академії (Херсон, Україна) fedorova.olena2406@gmail.com

Наталія БОБРИШЕВА, orcid.org/0000-0002-4449-954X кандидат педагогічних наук, доиент кафедри англійської мови в судноводінні Херсонської державної морської академіі (Херсон, Україна) natalyluchka1502@gmail.com

\section{МЕТОДИКА ЗМІШАНОГО НАВЧАННЯ МОРСЬКИХ ФАХІВЦІВ СТАРШИХ КУРСІВ ІЗ ЗАЛУЧЕННЯМ НОВІТНІХ ІНФОРМАЦІЙНИХ ТЕХНОЛОГІЙ}

У статті викладено методику імплементації сучасного освітнього підходу - мміманого навчання - у вивчення морської англійської із залученням онлайн-платформ. У ході дослідження встановлено, щчо навчальний процес у 
вищому навчальному закладі Херсонська державна морська академія інтегрує декілька видів навчальної діяльності за принципом змішаного навчання: традиційне навчання на засадах комунікативно-компетентнісного підходу й онлайн-навчання у форматі комп 'ютерних навчальних модулів. Упровадження методики змішаного навчання в Херсонську державну морську академію стало можливим шляхом використання закладом системи управління навчанням Moodle, щңо реалізує онлайн-навчання за асинхронним і синхронним підходами. Залучення викладачами комунікативно-компетентнісного підходу як до викладання морської англійської в аудиторіях (заняття за моделлю структур ESA), так і до побудови комп'ютерних навчальних курсів уможливило реалізацію повноцінного дистанційного навчання та поглибило соиіальний зв'язок між студентами старших курсів поза аудиторією. Організачія практичних занять саме за комунікативно-компетентісним підходом зумовлена, по-перше, його орієнтованістю на студента, а по-друге, фокусуванням на спілкуванні як в аудиторії під час практичних занять, так і поза нею - у реальному часі й сочіальних мережах. Ієрархічна структура навчання в рамках комунікативно-компетентісного підходу передбачає структурування великих тем за модулями, що своєю чергою розподілені на окремі одиниці (lessons), кожна з яких підпорядкована власній меті й взаємопов'язана з іншими. Побудова практичних занять та онлайн-курсів за такою структурою дозволяє взаємодоповнювати навчання в аудиторії онлайн-модулями й уможливлює поетапне опанування студентами англомовних компетениій. Оиінювання компетенцій містить комп'ютерне оцінювання за допомогою системи управління навчанням та оцінювання навичок говоріння майбутніх морських фахівиів у реальному часі віч-на-віч із викладачем. Проаналізувавши техніки комп 'ютерного оцінювання знань на базі платформи Моодle, ми встановили, щцо за змістом тести побудовані на основі реального контексту чи ситуачій на судні, а за формою переважають тести множинного вибору, тести на відповідність, тести на заповнення пропусків, представлені комбінаціями текстів, аудіо- й відеоматеріалів. Завершальне оцінювання англомовних компетенцій майбутніх морських фахівців відбувається методом інтерв'ювання та дискусії, щзо імітує реальні умови проходження професійної співбесіди.

Ключові слова: змішане навчання, комп'ютерне навчання, система управління навчанням, комп'ютерний навчальний модуль, комунікативно-компетентнісний підхід.

Formulation of the problem. One of the urgent problems inherent within most of the Ukrainian universities is the application of outdated approaches to teaching or focusing only on traditional models of teaching due to the "poor" material base of educational institutions and ignorance of specialists in modern teaching methods and informational technologies. As a result, there is a low level of student's interest in the learning process and its inefficiency as such.

The solution to this problem has become possible due to the widespread introduction and popularization around the world of the latest approach to learning "blended learning".

The key role of the latter is that this approach offers an innovative pedagogical implementation of a new model of learning that not only integrates the best aspects of traditional learning with modern information technology, but also offers the use of flexible teaching methods aimed at effective achieving of key competencies. Today, blended learning allows the instructor to take the learning process out of the classroom, offers diversify of curricula, improves students' access to learning resources and increases motivation to learn, "balancing" between learning opportunities such as learning in the classroom or face-to-face learning, collaborative or community learning and online learning.

Analysis of recent researches and publications. One of the strategies that has become key in the development of English language teaching methods over the last ten years is blended learning. Most foreign scholars (Graham, 2006; Caner, 2012; Hew, Cheung, 2014) define "blended learning" as a model of learning that includes three components: traditional classes under the guidance of an instructor, group and individual work of a student, online or computer learning. The advantage of this pedagogical approach over the previous ones is the combination of effective opportunities for socialization in the classroom or outside it with technologically advanced opportunities for active learning in the Internet environment (Dziuban, Hartman, Moskal, 2004). Thus, blended learning is aimed at combining two opposite paradigms - synchronous (classroom) and asynchronous (online learning) (Laster et al., 2005).

At present, blended or, as it is also called, "hybrid learning" is a fundamental rethinking of the learning model as a whole. It is not about the technologies themselves, but about shifts in the pedagogical model in focus of personalized, student-centered learning. The role of instructors is also changing: from information providers to coaches and mentors.

It is also a transition from the format of presenting information in the audience to active learning in a blended environment by immersing students in situations that encourage them to speak, read, search for information, and think critically.

Thus, we treat blended learning as an integrated learning process, mediated and controlled by the instructor, that combines the best aspects of traditional and online learning for effective achievement of the learning goal.

The aim of the study is to substantiate the methodology of blended learning on the example of KSMA, which aims at effective formation of the English-language competencies of maritime specialists by involving the latest technologies.

Research results. H. Staker and M. Horn (2012) distinguish four models of blended learning: 
1) rotation model, where students alternate online learning and classroom activities;

2) flexible model, where students study mainly online on their own schedule, and the instructor provides pieces of advice if necessary;

3) mixed model, where students supplement practical classes with additional online courses at their own discretion;

4) virtual model, where learning takes place mainly online, but with the possibility of instructor consultation.

At the KSMA, Maritime English instructors are currently training future maritime specialists in accordance to a mixed model, with students supplementing classes in classrooms with computerbased online modules.

"Computer learning" (e-learning) is learning via the Internet with the involvement of management systems, based on the principles of independence and activity (Martens et al., 2004). KSMA uses two approaches of computer learning:

- asynchronous, covering individual or group work, even if participants cannot be online at the same time through the media (e-mail, chats, social networks, forums, etc.);

- synchronous, when the learning process takes place in real time with the involvement of a group of students (the approach became possible within distance learning in period of a pandemic COVID-19 through conference programs Skype, Zoom or learning management system Moodle).

"Learning management systems" (hereinafter LMS) (web management systems) are web-based software platforms that provide an interactive learning environment on the Internet and automate the administration, organization, reporting on educational content and learning outcomes (McConachie et al., 2005).

LMS is used for blended and collaborative learning online: posting and supporting course materials on the Internet, familiarizing students with the course, tracking progress and establishing communication between students as their instructor (Watson, Watson, 2007). Although the LMS Internet environment has many features in common with traditional learning, it has unique features such as flexibility, mobility, time for reflection and anonymity. LMS can be implemented for students of any level of knowledge, because they promote communication in various formats (forums, chats, video conferences).

A key analytical feature of this tool is the ability to track the effectiveness of developed training systems, find gaps, make changes and continue to improve them.

A striking example of LMS, which works today around the world and is actively used in KSMA, is
Moodle. The system was developed on the basis of a constructivist philosophy, which emphasized the role of students as creators of content, not just spectators. Among the main functions of the Moodle platform are such as the ability to disseminate knowledge, assess competence, record student achievement, ensure communication between students and maintain system security (Turnbull et al., 2019).

The concept of "learning management system" is closely related to the concept of "computer training module" (hereinafter - CTM), which implements computer training of maritime English within asynchronous approach in KSMA. CTM is interpreted as computer training units that cover knowledge and skills on individual topics in their logical sequence. Thus, the content of a course is presented in the form of a series of computer modules, after which the student is tested for the level of mastery of the material studied.

In addition to the text part, CTM usually uses drawings, photographs, graphics, computer animations, interactive demonstrations, hyperlinks, a glossary, specialized databases, audio and video recordings of various formats. If the CTM includes summative assessment as a result of the acquired competencies, the LMS provides this assessment. However, the LMS is only a mechanism that needs to be filled with educational content. While CTMs make up in general this educational content. The integration of CTM with LMS provides feedback between the instructor and the future maritime specialist, makes the process of full-time learning flexible, and distance learning - full-fledged with the ability to assess objectively the competencies of students.

Under the latest social and information trends, where distance learning at KSMA has become an integral part of the educational process in a pandemic COVID-19, traditional full-time learning on the basis of communicative-competency approach and computer learning in asynchronous and synchronous approaches demonstrate high efficiency only if they are integrated.

In line with blended learning, which is used to form English-language competencies of future maritime specialists in senior courses, a teaching methodology has been developed by integrating a number of teaching activities with the involvement of modern information technology (Fig. 1).

(1) traditional learning on the basis of communicative-competency approach: the learning process in practical English classes at KSMA is student-oriented and organized in such way as to maximize the result, based on two key approaches communicative, which allows you to build classes 
on socio-cultural and socio-linguistic principles, and competency, which provides the ability of maritime professionals to solve certain types of professional problems on the basis of knowledge and skills acquired during training. Visually, the interaction of these approaches can be depicted in two planes: horizontal, which corresponds to the communicative principles of learning (language learning through language, active involvement in communication, appeal to real life and professional situations), and vertical, which allows gradual achievement of specific skills - competencies.

With a communicative approach there is a constant interaction of skills, appeal to the acquired skills and the involvement of knowledge on the studied topics. Under the competency approach with its hierarchical structure there is growth or layering of micro-skills, which constitute the productive part of each lesson, until a certain competency is formed.

The practical classes of senior students are based on the ESA model in the sequence "boomerang" (Engage, Activate, Study, Activate) or "patchwork" (Engage, Activate, Study, Activate, Study, Engage). We will describe these stages of the lesson in detail. The Engage stage is characterized by the activation of students in the classroom. The instructor adjusts them both to the study of maritime English as a whole and to the study of a particular topic of the course. At this stage, the instructor can use various dynamic techniques, such as changing students or involving unusual objects to present material, role play, simulation of a problematic situation, etc.

The Activate stage aims at working with the material (on the topic of the lesson), distinguishing between Activate 1 at the beginning of the lesson and Activate 2 at the end of the lesson. In the first case, students first become familiar with the topic and work on the tasks, based on their own experience of practice, which is a key difference, compared to students of 1 st and 2nd courses, where students don't have practice in real situations.

At the end of the lesson at the Activate 2 stage, students, using new knowledge on the topic, perform project tasks, act out problematic situations, simulate conversations on board and more. At the Study stage, students work with a lexical or grammatical task. The texts for the tasks must correspond to the topic of the lesson and be filled with those lexical or grammatical units that students can use in practice. Also, the tasks in this block are divided into preparatory (acquaintance with vocabulary or grammar rule), consolidation exercises (for example, fill in the gaps in sentences, write sentences using words) and productive exercises (the student demonstrates the acquired skills).

The structure of the "boomerang" is used both from the third year of study for students with complete secondary education, and for students enrolled in a abridged program after the Maritime College of KSMA and have the educational qualification of level "junior specialist". In the fifth year of the MA

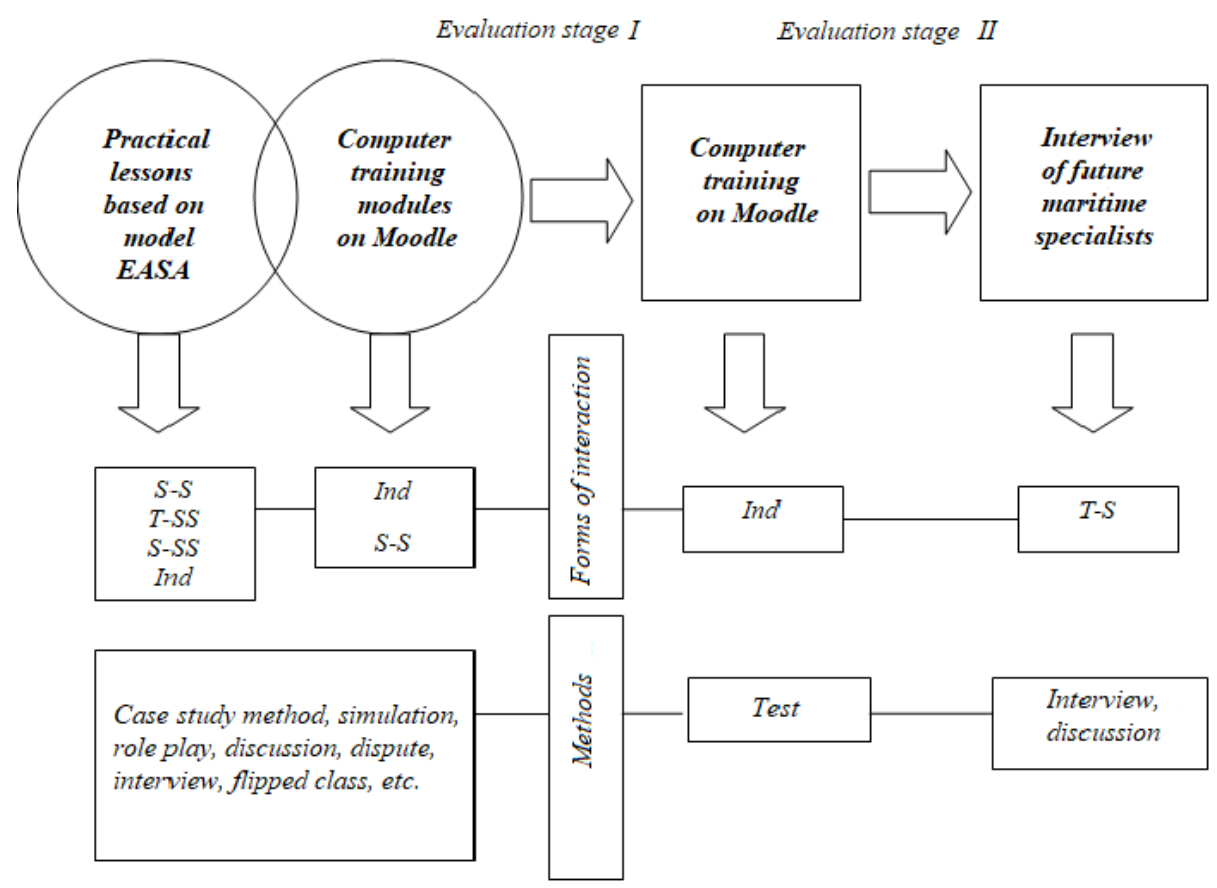

Fig. 1. Methodology of blended learning for maritime officers of senior courses 
course, the lesson model is based on the "patchwork" structure. The main difference between the structures is the unlimited number of Study stages and the availability of Activate 3 stage. However, these two structures are subjected to one goal - the formation of professional-oriented competency of the future maritime specialists. That means, the instructor can use lexical or grammatical blocks in any sequence, which are divided into small tasks, in comparison to one Study block in the "boomerang" structure. For example, this could be one task such as "insert lexical items into a sentence" after the Engage step, "fill in the gaps with words" after the Activate 1 step, and so on. Also in the fifth year, the Study and Activate stages are required to work with documents. For example, "fill in a report of cargo damage" using authentic professional phrases. At the last stage, it is mandatory to write your own document for the relevant situation (for example, "fill in the report on the damage to the bulk cargo"). Stage Activate 3 performs a professionaloriented function. At this stage, students demonstrate the professional competencies they have mastered. It is also obligatory to end the lesson with the instructor's comments on language mistakes during the productive task (project, acting out the situation, etc.).

Developed methodology allows to form understanding of the education's goal, speech skills in situations close to real professional activity onboard the vessel with a mixed crew. Students are motivated from the beginning of the lesson to practice skills, as well as simultaneously study lexical units or grammatical structures.

(2) computer training in the format of computer training modules: the hierarchical structure of each thematic module, which is held in the classroom, corresponds to the author's computer module, which not only contains audio and video materials involved in practical classes, but also complements practical classes with the help of LMS Moodle sharing tools. Author's training modules are used as a supplement to the lesson, which aims not only to deepen the knowledge of maritime specialists on a particular topic, but also to increase interest in discussion outside the audience (video and audio materials on discussion topics, cases for group discussion of problem situations, illustrations with tasks for development of critical thinking, game exercises to consolidate the material, reproduction of situations, collaborative projects). The main advantage of CTM is the provision of social communication between students outside the classroom and their effectiveness during distance learning. Teaching of the same training course can be conducted by several instructors at once, each of whom creates his / her own CTM.
An obligatory element in such a structure is the involvement of students in active work in the classroom through interactive tasks, pair or group work. Thus, at the Engage stage, the instructor checks the task that was performed by students at home online such as "study Internet resources on the subject of dry cargo and discuss in pairs / groups the main causes of its damage". The instructor can also offer to watch videos on the Moodle platform during the lesson, for example, about the procedure of ship inspections and their requirements with the task "fill in the table by categories": objectives of ship inspections, types of inspections, requirements for inspection of the ship, what documents must be prepared, etc.

An effective exercise is the use of Internet resources to search for information in collaborative projects. In groups, students prepare project work using online conference programs such as Zoom, Skype and during this process they "describe the procedures for coordinating the search and rescue operation", using the phrases of the Model Course IMO 3.17 (Model Course 3.17, 2015) for radio exchange, naming the problems that arise during search and rescue operations at sea, etc.

To work with documents on security procedures on board, the instructor offers to get acquainted with virtual documents of crew security, responsibilities and training on the Moodle platform and gives tasks in pairs to "fill in certain types of documents".

The introduction of virtual reality programs in Maritime English classes helps with the development of language skills in situations close to professional activities. In special classes on a virtual reality platform students perform professional tasks. All actions to be taken by the student are in English, so without understanding the maritime terminology it is impossible to pass all the tasks in the interactive program.

We will describe in detail one of the virtual simulators that can be used in classes with senior students (Fig. 2).

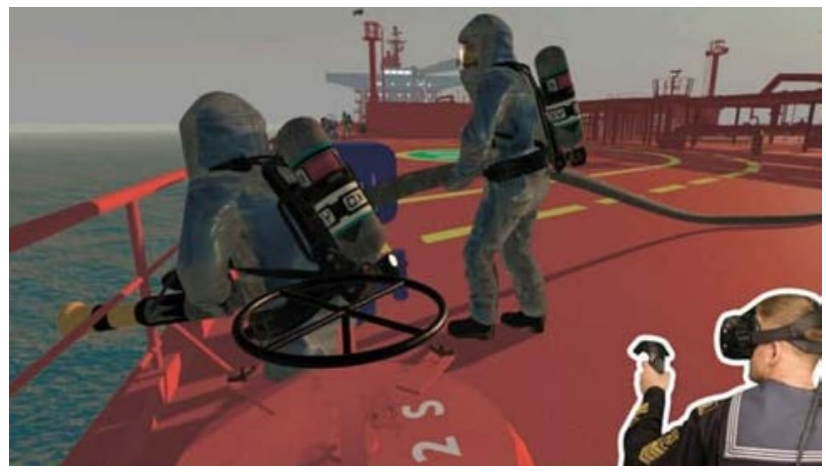

Fig. 2. Virtual Reality Simulator "Helicopter Operation" 
The Helicopter Operation Virtual Reality Simulator (List of Available Computer-Based Trainings, 2021) aims to introduce the team's theoretical knowledge and practical skills during helicopter operations. As a result of passing the simulator, students must show knowledge and skills of all procedures with a helicopter, safety rules, how to choose the right means of communication, knowledge of their actions in accordance with the position, following the safety plan.

To use such technologies, it is necessary to do a preparatory lesson. The instructor firstly practices maritime terminology, during the next stage students practice actions that need to be performed in a particular professional situation. Students receive additional homework on the topic.

After that, the instructor prepares a separate syllabus for classes using virtual reality. The first step is to familiarize students with the platform and remind about the security rules. The second step is to test the homework in order to consolidate the skills and practice them in virtual reality. By methods of game technologies the instructor checks the knowledge of maritime terminology. Next stage, the instructor divides the students into groups. Each group decides in what sequence students will perform actions in virtual reality. The first student begins and the second (third, etc.) continues to perform the following steps. In this way, students focus on each other's actions and perform tasks in one group as a team. The final stage of such a lesson is summarizing the results, working on mistakes.

In our opinion, the use of computer technology deepens the knowledge of maritime specialists on a particular topic, develops critical thinking, reproduces situations close to the professional conditions on board.

(3) computer-based assessment on the Moodle platform: test tasks are built in such a way as to test the cluster of competencies (linguistic, functional, strategic and sociolinguistic) in their unity. If in most computer databases of Maritime English testing (Marlins, MarTEL, TOME, TOMEC) gradation of test tasks is mainly carried out in the categories of "listening", "grammar", "vocabulary", "reading", and sometimes "writing", then in KSMA, Maritime English testing techniques and their content are based on the specific context of language usage, real-life communication situations on board (real-life scenarios). Separately selected grammar exercises are out of focus.

According to the analysis results of testing techniques on the Moodle platform, the priority is shared between multiple-choice tests - short answers based on texts, yes / no tests or compliance tests (true / false tests) - short answers used in reading and listening, rearrangement tests, gap-filling tests or short answers - are often used for testing vocabulary and application skills. The above types of tests are always presented in combinations with illustrations, video and audio materials (listening - multiple-choice tests, reading - yes / no tests, watching - gap-filling), which are as close as possible to the real conditions of communication on board.

In the context of the COVID-19 pandemic, computer assessment using the Moodle LMS demonstrated high efficiency and enabled an objective assessment of students' competencies at home. To this aim tasks in the format of additional written competencies were developed. For example, in the fifth year of the MA course, students pass such written competencies as "describe the procedures of ship inspections and their requirements", "describe the types of damage to cargo, their causes and precautions", "describe information about cargo documents and situations when they need to be filled", etc. The instructor tests not only knowledge of theoretical material, but also the use of grammatical structures and lexical units, content. The evaluation is based on the following criteria: the fullness of topic, the consistency of answer, whether the material is processed independently, or is copied from Internet sources, the number of grammatical errors, the usage of maritime terminology, the presence of judgments and conclusions.

Students create written texts on special pages of the platform, and the instructor can see and check these written competencies, make comments. Students can edit texts and work on errors online.

(4) real-time assessment of English-language competencies: techniques for testing students' level of these competencies coincide with the objectives of IMO Model Course 3.17 (Model Course 3.17, 2015) and may include such activities as "description of steps in the procedure (loading / unloading / emergency)" or "description of visitors appearance", "exchange of opinions / debates (changes in cargo transportation / actions in emergency situations)", "VHF communication (ship-shore / ship-ship)", "information exchange (routine actions / events on board /weather / types of vessels / solving problems related to the operation of equipment)", etc. Competency assessment is organized face-to-face with the instructor and the student using interview, discussion or debate methods depending on the level of language proficiency and awareness in the topic. Such conditions are as close as possible to the real professional interview that future maritime professionals will face during further employment. In addition, there is a practice of exchanging groups of students among instructors of Maritime English 
for assessment of competencies in order to achieve objective results.

In the context of the pandemic, the practice of online assessment of English-language competencies was developed through video conferencing programs Skype, Zoom and the Moodle platform.

In addition, a flexible assessment system has been developed as part of the blended learning methodology. Each type of work (demonstration of speaking competency, speaking exam, computer test, etc.) is evaluated from 5 to 15 points, depending on the number of modules per term. For example, in the first term of the fifth year of the MA course, speaking competencies are assessed with a maximum of 10 points, tests and written competencies (on the Moodle platform) with 10 points, study and analysis of cases (authentic maritime texts) after each module -5 points. In the first term, 4 modules are planned for study. Thus, the highest overall score for the evaluation of future maritime specialists by the rating system is 100 points.

The main criteria for assessing the demonstration of speaking competencies are the ability to answer questions using complete sentences, the presence of grammatical mistakes, speed of speech, speed of reaction, use of maritime English terminology, content.

In our opinion, speaking assessment is a complex procedure that fully illustrates the level of awareness and understanding of the material by senior students. It corresponds to the general purpose - preparation for real situations in the professional activity on the ship. After all, future maritime specialists work for a long time in crews of mixed nationalities, where they need to talk constantly, exchange information in English using maritime terminology.

Conclusions. The author's system of blended learning was developed and implemented in the educational process of KSMA in order to effectively achieve students' English-speaking competencies through the involvement of modern information technology. The uniqueness of this method lies in the integration of different educational and methodological activities, which were combined in KSMA on the principle of "mixed model" of learning. Thus, traditional teaching in classrooms on the basis of communicativecompetency approach (classes on the model of ESA structures "boomerang", "patchwork") is supplemented with online learning in the format of computer training modules at the Moodle platform. CTM tasks can be used both during fill-time classes in classrooms and outside them. Assessment of English-language competencies of maritime specialists integrates computer-based assessment of students on the Moodle platform in the form of tests and assessment of their skills in real time using an interview method. That is as close as possible to the professional employment procedure of future maritime professionals. This comprehensive blended learning methodology has enabled full-fledged distance learning in the pandemic conditions, demonstrated high effectiveness in objective assessing students' competencies online, and deepened the social bond between students outside the classroom.

The focus of further research is the involvement of microlearning elements in the methodology of blended learning on the basis of social networks and learning management systems.

\section{BIBLIOGRAPHY}

1. Caner M. The Definition of Blended Learning in Higher Education. 2012. URL: http://www.academia.edu/2115266/ Caner_M_2012_The_definition_of_blended_learning_in_higher_education_In_P_Anastasiades_Ed_Blended_Learning

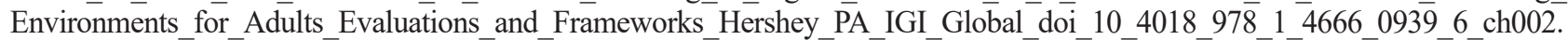

2. Dziuban C., Hartman J., Moskal P. B̈lended Learning. EDU $\bar{U} \bar{A} U S \bar{E}$ Review. $2004 . \overline{4}$ No. 7. P. $1-\overline{4} \overline{4}$.

3. Graham Ch. Blended Learning Systems: Definition, Current Trends, and Future Directions. Handbook of Blended Learning: Global Perspectives, Local Designs. San Francisco : Pfeiffer Publishing, 2006. P. 3-21.

4. Hew K. F., Cheung W. S. Using Blended Learning: Evidence-Based Practices. London : Springer Publishing, 2014. 123 p.

5. Redefining Blended Learning / S. Laster, G. Otte, A. Picciano, S. Sorg. Presentation at the 2005 Sloan-C Workshop on Blended Learning. April, 18. Chicago, 2005.
6. List
Available
Computer-Based
Trainings.
2021.
URL:

https://oms-vr.com/our-training/\#List_Of_Available_Computer-Based_Trainings.

7. Martens R., Gulikersw J., Bastiaensw T. The Impact of Intrinsic Motivation on Elearning in Authentic Computer Tasks. Journal of Computer Assisted learning. 2004. No. 20. P. 368-376.

8. Central Queensland University's Course Management Systems: Accelerator or Brake in Engaging Change / J. McConachie, P. Danaher, J. Luck, D. Jones. International Review of Research in Open and Distance Learning. 2005. No. 6 (1). P. 1-17.

9. Model Course 3.17. Maritime English. London : International Maritime Organization, 2015. 220 p.

10. Staker H., Horn M. Classifying K-12 Blended Learning. 2012. URL: http://www.christenseninstitute.org/wp-content/ uploads/2013/04/Classifying-K-12-blended-learning.pdf.

11. Turnbull D., Chugh R., Luck J. Learning Management Systems : An Overview. 2019. URL: http://www.researchgate.net/publication/335463920_Learning_Management_Systems_An_Overview. 
12. Watson W., Watson S. An Argument for Clarity: What are Learning Management Systems, What are They Not, and What Should They Become? TECHTRENDS TECH TRENDS. 2007. No. 51. P. 28-34.

\section{REFERENCES}

1. Caner,M.2012.TheDefinitionofBlendedLearninginHigherEducation.Availableat:http://www.academia.edu/2115266/ Caner_M_2012_The_definition_of_blended_learning_in_higher_education_In_P_Anastasiades_Ed_Blended_Learning

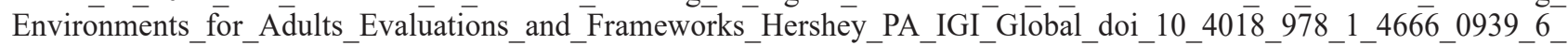
ch002.

2. Dziuban, C., J. Hartman, and P. Moskal. 2004. "Blended Learning.” EDUCAUSE Review. 2004 (7). pp. 1-44.

3. Graham, Ch. 2006. Blended Learning Systems: Definition, Current Trends, and Future Directions. Handbook of Blended Learning: Global Perspectives, Local Designs. Pfeiffer Publishing: San Francisco.

4. Hew, K. F., and W. S. Cheung. 2014. Using Blended Learning: Evidence-Based Practices. Springer Publ: London.

5. Laster, S., G. Otte, A. Picciano, and S. Sorg. 2005. "Redefining Blended Learning." Presentation at the 2005 Sloan-C Workshop on Blended Learning, Chicago.

6. List of Available Computer-Based Trainings. 2021. Available at: https://oms-vr.com/our-training/\#List_Of_Available_ Computer-Based_Trainings.

7. Martens, R., J. Gulikersw, and T. Bastiaensw. 2004. "The Impact of Intrinsic Motivation on Elearning in Authentic Computer Tasks." Journal of Computer Assisted learning. 20. pp. 368-376.

8. McConachie, J., P. Danaher, J. Luck, and D. Jones. 2005. "Central Queensland University’s Course Management Systems: Accelerator or Brake in Engaging Change." International Review of Research in Open and Distance Learning. 6 (1). pp. 1-17.

9. Model Course 3.17. 2015. Maritime English. International Maritime Organization. London.

10. Staker, H., M. Horn. 2012. Classifying K-12 Blended Learning. Available at: http://www.christenseninstitute.org/ wp-content/uploads/2013/04/Classifying-K-12-blended-learning.pdf.

11. Turnbull D., R. Chugh, and J. Luck. 2019. Learning Management Systems: An Overview. Available at: http://www.researchgate.net/publication/335463920_Learning_Management_Systems_An_Overview.

12. Watson W., and S. Watson. 2007. "An Argument for Clarity: What are Learning Management Systems, What are They Not, and What Should They Become?” TECHTRENDS TECH TRENDS. (51). pp. 28-34. 